\title{
CLOVE FARMING PERFORMANCE IN WAWOLESEA SUB DISTRICT NORTH KONAWE DISTRICT
}

\author{
Eriksan $^{\left.1^{*}\right)}$, Idrus Salam $^{1)}$, La Ode Alwi ${ }^{1)}$ \\ ${ }^{1}$ Department of Agribusiness Faculty of Agriculture Universitas Halu Oleo Kendari 93232 \\ ${ }^{*}$ Corresponding author : eriksanerik97@gmail.com
}

To cite this article:

Eriksan, E., Salam, I., \& Alwi, L. (2021). Clove Farming Performance in Wawolesea Sub District North Konawe District. International Journal of Agricultural Social Economics and Rural Development (ljaserd), 1(1), 17 - 23. doi:http://dx.doi.org/10.37149/ijaserd.v1i1.14160

Received: September 20, 2020; Accepted: October 31, 2020; Published: January 31, 2021

\begin{abstract}
This study aims to determine the performance of clove farming in the Wawolesea Sub District, North Konawe District. This research was conducted from July to September 2019. The population in this study were all farmers/heads of families who planted 110 cloves. The sample was determined by simple random sampling, namely by taking $15 \%$ of the total population of 32 respondents. The method used to analyze the data is a qualitative descriptive analysis method. The results showed that the performance of the cultivation/farming subsystem, namely a) land processing by using burnt and without burning, planting with a $5 \times 5 \mathrm{~m}$ cropping pattern, plant maintenance, with fertilization, carried out in the early rainy season, mid-rainy season and after harvesting, watering done in the morning and evening, making soil terraces, controlling pests and diseases by spraying and harvesting using wooden ladders and bamboo ladders.
\end{abstract}

Keywords: cloves farming; North Konawe District; performance; Wawolesea Sub District

\section{INTRODUCTION}

Agribusiness is a system consisting of upstream, farming, downstream, and supporting subsystems. According to Saragih (2010), the boundaries of agribusiness are a complete and interrelated system among all economic activities (namely the upstream agribusiness subsystem, the cultivation agribusiness subsystem, the downstream agribusiness subsystem, the agribusiness support services subsystem) which are directly related to agriculture.

Agribusiness can be defined as a system consisting of the following elements: (1) pre-harvest, (2) harvest, (3) post-harvest, and (4) marketing. As a system, agribusiness activities cannot be separated from one another, mutually integrated and interrelated. The disconnection of one part will cause the system to be unbalanced, while agribusiness activities cover the agricultural, fishery, and forestry sectors, as well as the industrial sector. The agricultural sector and the combination of the two sectors will create good economic growth nationally (Sumodiningrat, 2002)

Indonesia is a country that has considerable economic potential in various sectors. One of the sectors that support development in Indonesia is the agricultural sector. According to Saragih (2001), for Indonesia, activities based on the use of biological resources are controlled and managed mostly by the people who are the fundamental of its economy, both past, and present. More than $95 \%$ of entrepreneurs in Indonesia are entrepreneurs in the agricultural sector and around $80 \%$ of the population depends on their economic life in the agricultural sector (both based on food crops, horticulture, plantations, livestock, fisheries, and forestry).

The plantation sub-sector is part of the agricultural sector which has considerable potential in the Indonesian economy to increase foreign exchange, the fulfillment of raw materials, provide employment opportunities, and conserve natural resources. One of the plantation subsector commodities that are mostly cultivated by smallholders is cloves. Cloves are native to Indonesia, widely used as a spice in spicy dishes in European countries, and as the main ingredient in Indonesian kretek cigarettes. Currently, Indonesia is the largest clove producing country in the world, because it is a native Indonesian plant, also supported by natural conditions, climate, and topography that support clove agribusiness in Indonesia (Pusdatin, 2014). 
The development of the sustainable agricultural sector is the government's effort to increase the standard of living of the community by increasing the amount of farmer income in the agricultural sector through farming activities. Farming activities that provide opportunities to increase production that can increase community income in the agricultural sector by applying agricultural science in accordance with the research results of related institutions. Several agricultural commodities that are widely developed in Indonesia besides food are plantation products such as coconut, cloves, cocoa, oil palm, and others (BPS Sulawesi Tenggara, 2018).

Plantation plants such as cloves and coconuts are widely cultivated in Wawolesea Sub District, North Konawe District, especially in Otipulu Village, Lemobajo Village, Barasanga Village, and Toreo Village, which are the centers of producing these plants. However, over time and the increase in clove prices, which promises to increase the community's economy so that more clove farming is developed in the area, it is hoped that it will be able to increase farmers' income so that it will have a positive impact on the economy of the community in Wawolesea Sub District (BPS Kabupaten Konawe Utara, 2018).

In 2014-2015, clove production has increased, namely in 2014 clove production in Wawolesea Sub District reached 26.5 tons with an area of 199.0 hectares, and in 2015 clove production reached 40.1 tons with an area of 220.8 hectares. However, in 2016 the production of clove plants fluctuated, experiencing a decrease in production to 37.4 tons with an area of $237.6 \mathrm{Ha}$. In 2017, clove crop production again experienced a pretty good increase where the production of clove plants in 2017 reached 53.2 tons with an area of 250.4 Ha (BPS Kabupaten Konawe Utara, 2018).

BPS Kecamatan Wawolesea (2018) In Wawolesea Sub District, North Konawe District, there are farmers who cultivate clove plants. The production of clove plants in 2014-2017 shows that the production of clove plants is quite good, but this good clove production has not been able to meet the needs and encourage the economy of the community, especially clove farmers. In the agribusiness system, of course, it does not only discuss aspects of production but also discusses everything from the provision of production facilities and infrastructure, harvest, post-harvest, marketing to supporting aspects. Departing from this problem, the researcher wants to answer community problems by conducting research on the performance of clove farming in the Wawolesea Sub District, North Konawe District.

\section{MATERIALS AND METHODS}

This research was conducted from July to September 2019, at Otipulu Village, Wawolesea Sub District, North Konawe District. The location of this study was chosen purposively with the consideration that cloves are a commodity that is widely developed by the farming community in the area. This study uses qualitative data analysis from Miles and Huberman (1992) with a procedure to reduce data obtained at the research location (field data) as outlined in a complete and detailed description or report. The researcher's field reports were reduced, summarized and key points were selected, focused on important things, and then looked for patterns. During the data collection, there was a data reduction stage, then by making a summary, coding, tracing patterns, and writing theoretical memoranda. Presenting data to make it easier for researchers to see the overall picture or certain parts of the research focus and to draw conclusions/verification that is carried out continuously during the research. Since the beginning of entering the field and during the data collection process, the researcher attempted to analyze and look for the meaning of the words collected, namely: looking for patterns. The theme of the concurrent relationship, things that arise, hypotheses or so on to be poured in conclusions that are still temporary. Only with increasing data through a continuous verification process can conclusions be drawn.

\section{RESULTS AND DISCUSSION}

\section{Respondent Characteristics}

The characteristics of the respondents include the age of the respondent, the level of education, experience in clove farming, the number of dependents of the family, and the area of arable land they have. 
Table 1. Characteristics of respondents

\begin{tabular}{|c|c|c|c|}
\hline No. & Variable & Number (people) & Percentage (\%) \\
\hline & Age (Years) & & \\
\hline & $15-54$ & 28 & 87,5 \\
\hline & $>54$ & 4 & 12,5 \\
\hline \multirow[t]{7}{*}{2.} & Level of education & & \\
\hline & Not finished & 2 & 6,25 \\
\hline & Graduated from SD / SR & 15 & 46,88 \\
\hline & Completed SMP / MTs & 7 & 21,88 \\
\hline & Completed SMA / SMK & 5 & 15,62 \\
\hline & Completed D3 & 1 & 3,12 \\
\hline & Graduated S1 & 2 & 6,25 \\
\hline \multirow[t]{3}{*}{3.} & Family dependents (soul) & & \\
\hline & $1-4$ & 25 & 78,12 \\
\hline & $>4$ & 7 & 21,88 \\
\hline \multirow[t]{4}{*}{4.} & Farming Experience (years) & & \\
\hline & $<5$ & 1 & 3,12 \\
\hline & $5-10$ & 10 & 31,26 \\
\hline & $>10$ & 21 & 65,62 \\
\hline \multirow[t]{4}{*}{.5 . } & Land Area (ha) & & \\
\hline & $<0,5$ & 5 & 15,62 \\
\hline & $0,5-2$ & 26 & 81,26 \\
\hline & $>2$ & 1 & 3,12 \\
\hline
\end{tabular}

Source: Primary Data, 2019

Age is one of the factors that can affect a person's ability to work. The older a person is, the less his ability will be. Most of the respondents are still classified into the productive age, so they have a level of ability that allows them to run farming. The results showed that the age of the farmer respondents was $87.5 \%$ or as many as 28 people were aged $15-54$ years, while those who were at the non-productive age above 54 were 4 people (12.5). This indicates that respondents generally have a dynamic attitude in carrying out activities related to their farming. According to Soeharjo and Patong (1984), the productive age category starts from 15-54 years old and the rest is in the nonproductive age category.

Table 1 shows that the highest level of education for clove farmers is that of SD / SR as many as 15 people. There were 2 farmers who did not complete, 7 people graduated from SMP / MTs, 5 people graduated from SMA / SMK, 1 person graduated from D3 and 2 people graduated from $\mathrm{S} 1$. It can be seen that the level of education of clove farmers is relatively low. Education is one important factor that can influence the farmer's mindset in running his farm. The higher the education of farmers, the higher their absorption of new technology and innovations that are developing compared to farmers with low education.

Table 1 shows that the largest number of respondent family members, namely between 1-4 people (small family) as many as 25 people $(78.12 \%)$ and $>4$ people (large family) as many as 7 people $(21.88 \%)$. Seeing the size of the farmer family members, it can be concluded that farmers are included in the category of small families with a total of 1-4 people (Soeharjo and Patong, 1984). The size of the family members is one of the socio-economic factors that play a role in increasing farmer production. The size of family members is a human resource that is developed to help the head of the family in farming, especially for family members who are of productive age who will give their money in farming production. In the position of head of the family and community members, farmers try to meet the needs of their families. Whether or not the number of family members affects the availability of the number of family workers so that farmers who have a large number of dependents will tend to operate relatively large farms.

Table 1 shows that most of the respondent farmers are experienced in farming, namely for $<5$ years (less experienced) 1 person (3.12\%), while the respondent farmers who are 5-10 years old (experienced enough) are 10 people $(31,26 \%)$ and respondents who are farming $>10$ years (experienced) are 21 people (65.62\%). Experience is an educational process that is obtained outside of school from an event or events that have been experienced which is very useful for someone to do good things from before, especially the experience of trying to develop managed farming. The experience of farming is very helpful for doing better in the future. Based on the existing experience, it is hoped that farmers will be able to develop and manage their farms well. Soeharjo and Patong 
(1984) categorized three categories of experience in farming, namely less experience ( $<5$ years), moderately experienced (5-11 years), and experienced ( $>10$ years). Experienced and young farmers have a more mature farm management capacity and are more careful in their actions compared to relatively old and inexperienced farmers.

Table 1 shows that most of the respondent farmers have a medium area of farming land, which is between $0.5-2$ hectares, with 26 respondents $(81.26 \%)$, while the respondent farmers have cultivated land $<0,5$ hectares (narrow) as many as 5 people $(15.62 \%)$ and respondent farmers who have a land area of $>2$ hectares (area) as many as 1 person (3.12\%). The land area used by farmers will affect the level of production that will be achieved by each respondent farmer. Land in agriculture is a very important business capital because the farmer's land can support his family, as an important factor, all activities from the land play an important role in obtaining yields, an increase in the yield of cultivated crops which is of course greatly influenced by the ability of farmers to manage the land. well. The land is very influential on farm income. Land factors that affect farm income are arable land area, physical condition, soil fragmentation, the land location from the economic center, and land tenure status. In general, it is said that the wider the land (cultivated/cultivated), the greater the number of products produced by the land (Rahim and Hastuti, 2008). Hermanto (1991) distinguishes three groups of farmers based on the area of land they cultivate, namely narrow arable land $(<0.5 \mathrm{ha})$, medium arable land area (0.5-2ha), and wide arable land area ( $>2 \mathrm{ha}$ ).

\section{Clove Farming}

The farming subsystem is an activity to cultivate clove plantations from planting to harvest. Currently, clove plants have an average age of 5-50 years of production. Until now, it is not known at what age clove plants will die and not produce. Therefore, the process currently carried out by clove farmers is only maintenance. The following is the process of planting cloves from planting to harvest.

\section{a. Land processing}

Land processing is a land preparation activity aimed at obtaining land that is ready for planting and free from physical disturbances such as pests and weeds. According to farmers 'information, land processing was first carried out by clearing it, and then the grass was burned and some were left alone, but based on the observations of the respondent farmers' information, most of the grass that had been cut was not burned. The way to cultivate the land of the respondent farmers can be seen in Table 2

Table 2. Number and percentage of respondent farmers' land processing in Wawolesea Sub District, Konawe Utara District

\begin{tabular}{cccc}
\hline No. & Land Processing & Number (people) & Percentage (\%) \\
\hline 1. & Clean tripe / burn & 10 & 31,25 \\
2. & Clean tripe / without burning & 22 & 68,75 \\
\hline & Total & 32 & 100 \\
\hline
\end{tabular}

Source: Primary Data, 2019

Table 2 shows that most of the farmers' land processing cleared tripe / without burning it, as many as 22 people $(68.75 \%)$, while the respondent farmers who cleaned slash / burned were 10 people $(31.25 \%)$.

\section{b. Planting}

Planting clove seeds is carried out after land processing activities, put the clove seeds into the planting hole that has been prepared $1 \mathrm{~m} \times 1 \mathrm{~m} \times 50 \mathrm{~cm}$, then fill it with soil as high as the middle of the clove seedling, compact the soil, water it with enough water. According to farmers' information, there is no fertilization before planting, after that sticking the pieces of wood in addition to the clove seeds that have been planted serves to provide protection against physical pests and is also added with pieces of coconut leaves as protection from the sun. On average, most clove farmers currently use a spacing of $5 \times 5 \mathrm{~m}$. According to farmers, the initial spacing was $7 \times 7 \mathrm{~m}$. However, over time and the decreasing area of land owned by farmers and the many experiences of farmers in growing cloves, farmers changed their clove planting pattern from $7 \times 7 \mathrm{~m}$ to $5 \times 5 \mathrm{~m}$. The spacing pattern of cloves can be seen in the image below: 


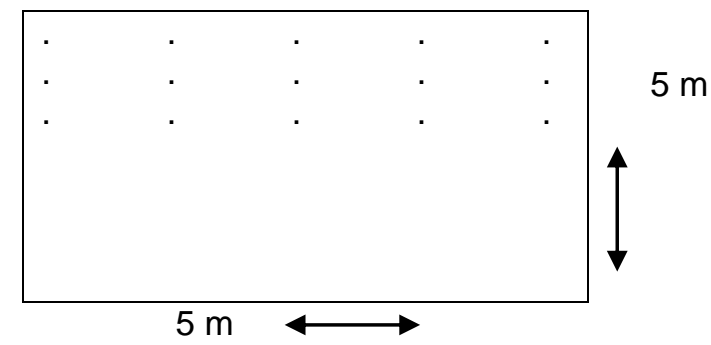

Figure 1. Respondent farmer's clove plant distance pattern

Based on the results of my research, according to farmers planting cloves with a spacing pattern of $5 \times 5 \mathrm{~m}$. it is good for growth, development, and production produced by clove plants every year. Even though ideally the spacing pattern of cloves is $7 \times 7 \mathrm{~m}$. because it has a lowland category area. The clove spacing patterns of respondent farmers can be seen in Table 3.

Table 3. Number and percentage of clove planting distance patterns in Wawolesea Sub District, North Konawe District

\begin{tabular}{cccc}
\hline No. & Spacing Patterns & Number (people) & Percentage $(\%)$ \\
\hline 1. & $7 \times 7 \mathrm{~m}$ & 6 & 18,75 \\
2. & $5 \times 5 \mathrm{~m}$ & 26 & 81,25 \\
\hline & Total & 32 & 100 \\
\hline
\end{tabular}

Source: Primary Data, 2019

Table 3 shows that the pattern of spacing of the respondent farmers is mostly $5 \times 5 \mathrm{~m}$ as many as 26 people (81.25\%), while the respondent farmers who use the spacing pattern of $7 \times 7 \mathrm{~m}$ are 6 people (18.75\%).

c. Plant care

\section{Fertilization}

Clove farmers in the research location fertilize using 3 types of fertilizers, namely Guano, NPK, and Poprof fertilizers. Fertilization of clove plants is carried out so that the cloves do not lack nutrients from the soil, because it will inhibit the growth, development, and production processes produced by clove plants. The time of fertilization, the type and dose of fertilizer for farmers' clove plants can be seen in Table 4

Table 4. Types and doses of fertilizer pear tree for clove plants, Wawolesea Sub District, North Konawe District

\begin{tabular}{lccc}
\hline \multirow{2}{*}{ Time of Fertilization (Age) } & \multicolumn{3}{c}{ Type and Dose of Fertilizer } \\
\cline { 2 - 4 } & Guano Fertilizer (Kg) & NPK Fertilizer (Kg) & Poprof Fertilizer \\
\hline $1-5$ years after planting & $1-3$ & - & - \\
$5-10$ years after planting & $5-10$ & $0,2-0,3$ & 1 tablespoon \\
10-25 years after planting & $10-15$ & $0,3-0,5$ & 1 tablespoon \\
$>25$ years after planting & $15-20$ & $0,5-1$ & 1 tablespoon \\
\hline
\end{tabular}

Source: Primary Data, 2019

Table 4 shows that the dosage of Guano fertilizer and NPK fertilizer varies depending on the age of the clove plant after planting, while the use of dosage for Poprof fertilizer does not depend on the age of the clove plant. Based on the results of the research, a small number of farmers did not use any fertilizers. According to the respondent farmers, the use of Guano fertilizer is scattered beside the tree following the canopy of the clove plant and then loosened with the soil so that it is mixed after that it is watered with enough water, while the use of NPK and Poprof fertilizers is by making 4 holes $50 \mathrm{~cm}$ deep around the clove tree following the clove plant canopy then Poprof and NPK fertilizers are put into the excavation of the holes that have been provided and watered with enough water to help dissolve the fertilizer in the soil after which the hole is closed again with soil. The time of fertilizing the respondent farmers can be seen in Table 5 below. 
Table 5 Total and percentage of fertilization time for respondent farmers in Wawolesea Sub District, Konawe Utara District

\begin{tabular}{clcc}
\hline No. & \multicolumn{1}{c}{ Fertilization Time } & Number (people) & Percentage (\%) \\
\hline 1. & The beginning of the rainy season & 16 & 50 \\
2. & The middle of the rainy season & 9 & 28,12 \\
3. & After harvest & 4 & 12,5 \\
4. & Not fertilizing & 3 & 9,38 \\
\hline \multicolumn{2}{c}{ Total } & 32 & 100 \\
\hline
\end{tabular}

Source: Primary Data, 2019

Table 5 shows the time of fertilization of the respondent farmers mostly at the beginning of the rainy season as many as 16 people (50\%), while the mid-rainy season is 9 people $(28.12 \%)$, fertilization after harvest is 4 people (12.5\%) and those who do not fertilize as many as 3 people $(9.38 \%)$.

\section{Watering}

Based on the research results, farmers do watering in the dry season every morning and evening because clove plants cannot withstand the heat in the dry season, which can cause the clove tree to die. As for the dose of water per one tree as much as one jerry can be more every day in the dry season. However, there are some respondent farmers who do not water because there is no water available near the clove farm.

\section{Making the terraces of land}

Respondent farmers in the research location made land terraces on sloping land to help collect water in the rainy season, making soil terraces on the top of the clove tree to the end of the clove leaf crown.

\section{Pest and Disease Control (OPT)}

Based on the results of research on pest and disease control by respondent farmers, depending on the pests and diseases that attack the clove plant, according to farmers the types of pests and diseases that exist in the research location, namely:

- Stem borer, symptoms of attacking clove tree trunks, according to farmers, this stem borer is the main pest, how to control it is sprayed with an adequate amount of insecticide.

- White leaf pests, the symptoms attack directly on clove leaves according to control farmers by opening / cleaning the white leaf pests, for now, there is no other way.

- Fungus or moss, the symptoms are immediately visible on the clove tree, be it stems, leaves, and twigs, how to control it is opened/cleaned, which is separated from the clove tree.

- Dead branches, symptoms interfere with the growth of young leaves, how to control the dead twigs are broken/cleaned.

According to the respondent farmers in the location of research on pest and disease control (OPT), it was carried out when the symptoms were already there, as long as the symptoms had not been seen or the condition was fine, there was no control action taken by the farmers.

\section{d. Harvest}

Based on the results of the research, the age of clove plants in the location of the noble study resulted in production from 5 to 6 years, according to the early farmers, cloves began to produce depending on soil conditions. If the age of the cloves has reached the age of 10 years and over, the resulting production has started to a maximum, which is around 60 to 100 liters/clove tree, according to farmers there is no limit to clove production the older the clove tree is, the more production is produced.

Harvesting of clove fruit/flowers is done once per year because the clove plant is a seasonal/long-term crop. Apart from the clove flowers/fruit that are harvested, there are also those of economic value, namely the stalk of the clove fruit/flower at a price of Rp. 3,000 to $R p .4,000 / \mathrm{kg}$ of the dried stalk, while the leaves are not traded due to the lack of knowledge of farmers, and no technology is used to process. According to farmers, the dead clove leaves are used as fertilizer and protection in the dry season. The process of harvesting clove fruit/flowers is carried out when the cloves have started to turn red and emit pollen, a sign that the cloves are ready to be harvested. According to farmers harvesting cloves using a one-foot ladder made of wood and a two-foot ladder made of bamboo, the harvesting process usually starts from May to November because the cloves 
don't usually ripen at the same time. According to farmers, harvesting cloves sometimes uses labor from close families and local villagers as many as 1 to 4 people, with a salary or wage of IDR 80,000 / day (8 hours of work).

\section{CONCLUSION}

The performance of the cultivation/farming subsystem, namely a) land management by burning Babat and without burning Babat, planting with a $5 \times 5 \mathrm{~m}$ cropping pattern, plant maintenance, with fertilization carried out at the beginning of the rainy season, mid-rainy season and after harvest, watering is carried out in the morning and evening, making soil terraces, controlling pests and diseases by spraying and harvesting using wooden ladders and bamboo ladders.

\section{REFERENCE}

BPS. (2018). Badan Pusat Statistik Kecamatan Wawolesea dalam Angka. BPS Kecamatan Wawolesea. Wawolesea

BPS. (2018). Badan Pusat Statistik Konawe Utara dalam Angka. BPS Konawe Utara. Andoolo

BPS. (2018). Badan Pusat Statistik Sulawesi Tenggara dalam Angka. BPS Provinsi Sulawesi Tenggara. Kendari

Hermanto, 1991. Ilmu Usahatani. Penebar Swadaya, Jakarta

Miles, B. M., \& Huberman, M. (1992). Analisis Data Kualitatif Buku Sumber Tentang Metode-Metode Baru. UIP. Jakarta

Pusat Data dan Sistem Informasi Pertanian (Pusdatin). (2014). Statistik Hortikultura. Sekretariat Jendral Kementrian Pertanian. Jakarta.

Rahim, A., \& Hastuti, D. R. D. (2008). Pengantar, Teori dan Kasus Ekonomika Pertanian. Penebar Swadaya. Jakarta.

Saragih, B. (2001). Suara dari Bogor : Membangun Sistem Agribisnis. Yayasan USESE bekerjasama dengan Sucofindo. Bogor.

Saragih, B. (2010). Agribisnis: Paradigma Baru Pembangunan Ekonomi Berbasis Pertanian, Kumbang. Edisi Ketiga. PT Penerbit IPB Press. Food and Agribusiness Center.

Soehardjo A., \& Patong, D. (1984). Sendi-Sendi Pokok Ilmu Usahatani. Universitas Hasanuddin, Ujung Pandang.

Sumodiningrat, G. (2002). Pengantar Ekonometrika. BPFE. Yogyakarta 